\title{
Understanding public Euroscepticism
}

Citation: Simona Guerra (2020) Understanding public Euroscepticism. Quaderni dell'Osservatorio elettorale - Italian Journal of Electoral Studies 83(2): 45-56. doi: 10.36253/qoe-9672

Received: September 4, 2020

Accepted: December 17, 2020

Published: December 23, 2020

Copyright: $(2020$ Simona Guerra. This is an open access, peer-reviewed article published by Firenze University Press (http://www.fupress.com/qoe) and distributed under the terms of the Creative Commons Attribution License, which permits unrestricted use, distribution, and reproduction in any medium, provided the original author and source are credited.

Data Availability Statement: All relevant data are within the paper and its Supporting Information files.

Competing Interests: The Author(s) declare(s) no conflict of interest.

\author{
Simona Guerra \\ University of Surrey, United Kingdom, 0000-0003-3911-258X \\ E-mail: s.guerra@surrey.ac.uk
}

\begin{abstract}
Euroscepticism has become more and more embedded both at the EU and national levels (Usherwood et al. 2013) and persistent across domestic debates (Usherwood and Startin 2013). This study presents an in-depth analysis of contemporary narratives of Euroscepticism. It first introduces its question related to understanding public Euroscepticism, following the British EU referendum campaign and outcome, to then present the established literature, and the analysis of the British case study. A survey run in Britain in May 2019 shows that, as already noted by Oliver Daddow (2006, 2011), Euroscepticism is very much identifiable in the traditional narratives of Europe as the Other. Context accountability (Daddow 2006) is still cause for concern in Britain and by assuming a more positive view of a European Britain (Daddow 2006) does not make the debate more informed. Images, narratives and specific issues to reform the Eurosceptic toolbox into a more neutral, but informative, instrument could be applied at the grassroots level, as the post-referendum demonstrations and manifestations have shown. British citizens are reclaiming their own European citizenship, and deconstructing existing Euromyths can be a first small step forward.
\end{abstract}

Keywords. Euroscepticism, public opinion, Brexit; narratives.

\section{INTRODUCTION}

On Saturday, $2^{\text {nd }}$ July 2016, thousands of people marched through London to show their support for the EU (European Union) and in protest against the UK (United Kingdom) EU membership referendum (23 June 2016) result, when 51.9 per cent of British citizens voted Leave. Gathering around Park Lane, demonstrators walked up to Parliament square within a wave of EU flags and placards, reading slogans as 'We Love EU', 'Never gonna give EU up' and 'Brexshit'. One of the organizers, Mark Thomas, commented that he felt 'anger [and] frustration' and needed to do something (BBC 2016).

A few months later, after the EU institutions received the UK Prime Minister Theresa May's notification letter triggering Art. 50 (29 March 2017), the EU Council President Donald Tusk (2017) gave his official speech by closing on an emotional tone, '...we already miss you.' On a similar note, the European Parliament (EP) Brexit Coordinator Guy Verhofstadt talked of the letters he had been receiving, and the emotion coming up nearing the opening of the negotiation to exit the EU (BBC 2017). 
The 2016 British referendum shows that, theoretically, identity, rational utilitarian frameworks of analysis, political parties' cues or other quantitative analyses cannot fully explain its outcome. Narratives, and embedded national discourses, are missing from the overall picture. Yet, narratives engage through psychological realism, such as the red bus used in the British Leave campaign, and mobilize emotions. The role of narratives is critical to examine how people relate to the EU and what Euroscepticism is about. Recent EU crises reclaim the urgency of understanding how the EU is represented and articulated to accept the challenge of the persistent distance between the EU and citizens. This study focuses on the narratives that mobilize public Euroscepticism that emerged after the British EU referendum, examining what the narratives are and what they tell us about public Euroscepticism.

When studying public attitudes at the end of the 1990s and early 2000s, before the EU enlargement, the focus tended to examine decreasing levels of support, across member states and candidate countries - ie.: mainly Central and Eastern European (CEE) countries. In Poland, the largest of the EU candidate countries, and member states, as in Germany and Austria, citizens were fearing the social costs of the negotiation reforms in the former cases, and floods of immigration from neighbouring countries, in the latter. Identity, rational utilitarian frameworks of analysis or the study of the relationship between attitudes towards the nation state and democracy, or political cues could explain general patterns of support and opposition, where a ratio between costs and benefits determined attitudes in the Eastern region (Guerra 2013), and domestic politics could affect attitudes across Western member states (Guerra and Serricchio 2014).

Since then, research has also sought to explain that public Euroscepticism is different compared to party Euroscepticism. With the Treaty of Maastricht (1992), when public opinion became for the first time 'both a measure and a determinant of the process of European integration' (Gabel 1998: 9), studies developed more to explain than to understand public Euroscepticism.

This analysis first explores why it is fundamental to address a question on understanding Euroscepticism, following the British EU referendum campaign and outcome, to then present the established literature on Euroscepticism, and key concepts and contributions. The analysis of the narratives on the British referendum shows how generalizations can be challenging and people's voices are critical to understand the main embedded themes and dimensions of opposition to the EU. While these are mainly explanatory at the domestic level, this research suggests that a comparative analysis could offer an essential overview to understand public Euroscepticism.

\section{WHY 'UNDERSTANDING’ EUROSCEPTICISM}

Euroscepticism has long remained under-examined in its meanings and manifestations across

the public, with some notable exceptions investigating civil society, the European public sphere or lack of it, and the role of the media (Dutceac Segesten and Bossetta 2019; Bijsmans et al. 2018; Eurosphere 2013; FitzGibbon 2013). The financial and refugee crises first and the British referendum, since 2016, have brought contestation to the forefront, and scholarly debates have started to examine the opposition that started to increase in the postfinancial crisis years (Usherwood et al. 2013; Caiani and Guerra 2017; Stefanova 2014; Guerra and Serricchio 2014), and its national differences (De Vries 2018). This analysis suggests that listening to the different voices could have helped understand the British referendum outcome.

As noted for the case of identity (Risse 2010), attitudes become more salient at times of crisis, and by investigating the national narratives and emotions attached, in the UK after the referendum, this study seeks to stress the relevant characteristics of the domestic politics of EU integration at the public level and the debates originated within that context, and the narratives that have been mobilized across public opinion, listening to people's voices. Recent contestations address the idea of the EU in the Treaties, and John FitzGibbon suggests the term 'Euroalternativism', to indicate 'prosystemic opposition' that proposes alternative policies and institutional reforms, while arguing that 'another Europe is possible' (2013). Almost fifteen years ago, Taggart (2006) suggested proceeding by examining domestic politics, as dynamics at the domestic level are critical to understand Euroscepticism. Thus, this analysis seeks to reconcile two fields of studies, European domestic politics and European Studies (Hutter et al. 2016), bearing in mind that public Euroscepticism is not likely to be explained by party models. Public Euroscepticism can show apathy towards politics in general, and low salience of the EU (see Guerra 2013). At the public level, Euroscepticism can be represented by a more passive, attitude, against some policies or due to the perceived distance of the EU institutions, while the Greek referendum in 2015 and the British referendum in 2016 show how debates can radicalize and create, what Tsebelis calls, an emerging tribalism, 'division into non-communicating competitive groups in political and social life' (2018: 81). 
Consequently, the objective here is to examine the different narratives of Euroscepticism, exploring the indepth understanding of its manifestation, and its articulation emerging at the domestic level, in the Brexit case study. It is in the different embedded traditions, nuances and messages, and lack of messages, at the domestic and EU levels, that we can understand public Euroscepticism.

\section{KEY CONCEPTS, ANALYTICAL FRAMEWORK AND PREVIOUS RESEARCH ON THE TOPIC}

The core interest is the voices of Euroscepticism in their emergence and narratives at the domestic level to offer a tool that can be applied in comparative perspective. The assumption is that this approach is critical to understand public Euroscepticism, as it would examine it within its own environment, while still applying a comparative perspective. The years of publication of the different contributions on Euroscepticism emerged across the European Studies research in the early 1990s, following the unexpected impact of citizens' opposition to the elite driven development of the EU integration process. At that time, the urge of new theories led to a new contribution, postfunctionalism (Hooghe and Marks 2009), seeking to explain unprecedented contestation towards the EU, emerging from more heated debates at the public level. The Danish rejection of the Treaty of Maastricht (1992) signaled a turning point, as the legitimacy of the EU became more challenged. The definition of Euroscepticism commonly used is provided with reference to political parties, as 'the idea of contingent or qualified opposition, as well as incorporating outright and unqualified opposition to the process of European integration' that can be 'on principle', too 'inclusive' or too 'exclusive' (Taggart 1998: 365-366). Taggart's typology later develops towards a taxonomic approach and distinguishes between 'soft' and 'hard' party Euroscepticism. The former defines when 'there is NOT a principled objection to European integration or EU membership', but opposition to one or more policies or the party opposes the EU because it may be against the 'national interest' and the latter indicates 'a principled opposition to the EU and European integration', usually in those political parties aiming to withdraw their country from the EU or opposing EU integration or further developments (Taggart and Szczerbiak 2002: 7).

An alternative explanation, based on a 'two-dimensional conceptualization' (Kopecký and Mudde 2002), and an ideological dimension, distinguishes diffuse and specific support for European integration, indicating support for the 'general ideas' and support for the 'general practice' of the EU integration process. The limits of the theoretical exercise emerge with the Europragmatist category, where a political party opposes the EU, but supports further developments of the EU integration process. Aleks Szczerbiak and Paul Taggart's analysis has remained for party analyses, but also to indicate public forms of opposition. Yet, public Euroscepticism does not show the same stances of party Euroscepticism. In this research, the scope is to understand the emotional mobilization and effectiveness of narratives at the public level, that have become clear with the 2016 British referendum.

\section{HOW BREXIT CHANGES PUBLIC EUROSCEPTICISM}

Brexit has created new directions of research, that answer the urgency of understanding how the EU is represented and articulated to accept the challenge of the persistent distance between the EU and citizens, beyond parties and institutions. As Flood had already observed, Euroscepticism presents challenges, as Eurosceptics can blame the EU for excessive regulation and intervention, on the right, or being committed to liberalism, on the left, and represents a 'multitude' of types and viewpoints (Flood 2002). This develops

in the embedded traditions and narratives, or discourse, at the domestic level (Usherwood and Startin 2013; Daddow 2013).

The British referendum played the role of decisive turning point. A turning point or crisis is based on a construction that posits the Self vs. the Other. This returns in the everyday lived experiences, where the national context is contrasted with the international narrative, as foreigner, well represented by Brussels, and the EU (see Wodak and Angouri 2014). National political actors can use a critique for 'internal necessities' (Wodak and Angouri 2014: 418), with 'blame' entering the narrative (Guerra 2019; see also Krzyżanowski 2019). The media and social narrative helped to renegotiate the campaign to 'take back control', and sustain the fear of immigrants, leading to anxiety, day by day, creating a daily storytelling in the newspapers. Local communities were mobilized by holding together against the Other.

The rhetoric deployed by both camps generated anxiety, uncertainty, anger and disappointment, and brings the study of emotions to the centre of the analysis. Emotions have been at the centre of studies since Aristotle, Plato and Hobbes (Marcus 2000), and have recently returned also across different fields of research (de Boise and Hern 2017). The notion of affect re-emerged in humanities and social sciences during the 1990s. Draw- 
ing upon Spinoza and Deleuze, the corpus of 'affect theory' has since then gained momentum in the scholarly circles of social sciences. The advocates of affect agree in general that the notion is worthy of scientific attention as an 'entity', a 'being' or 'becoming' independent from the realm of cognition. Emotion is qualified intensity, the conventional, consensual point of insertion of intensity into semantically and semiotically formed progressions, into narrativizable action-reaction circuits, into function and meaning. (Fanoulis and Guerra 2017) It appears that both campaigns had an influence in increasing citizens' apprehension and uncertainties, across different age cohort. Still, while women and young people tend to be more anxious or uncertain, men are likely to feel angry and disappointed; among their open answers (Guerrina et al. 2016) the possible challenges towards the future and the lack of stable expectations and probable economic instability are likely to have played a role on voters. The increasing salience of the domestic debates viewed the British referendum open a wealth of emotions attached to EU membership, in particular after the result became clear in the morning of June 24 th, which, this study suggests, have created a turning point in the study of EU integration and Euroscepticism, and require a more in-depth study, in its everyday narrative and emotional dimensions.

\section{Beyond the limits of the study of public Euroscepticism}

Both the Sussex and North Carolina Schools have had limited scope for widespread expansion, beyond the study of party-based Euroscepticism. Studies on public support mainly apply frameworks to understand citizens' attitudes towards the EU, with a focus on different aspects of the relationship between public opinion and domestic politics. A changing political Union, with the Treaty of Maastricht, brought to the study of rational utilitarian and affective dimensions of attitudes (Gabel 1998). In Gabel's study, emerging from the determinant role that public opinion was currently playing, the utilitarian changes according to the benefits and is shaped by domestic politics. For these reasons, it could be to a certain extent unstable. The affective dimension, embracing abstract values and commitments to an idea, generally correlates with the length of membership and results more stable. The analysis is contingent to the post-Maastricht EU policy development, but well describes how the different national dynamic relations between the utilitarian and affective dimensions can change (Gabel 1998: 103) and impact levels of support. Emotions are becoming more and more significant, in particular as studies show that citizens may have a limited knowledge on the EU political system, because of its complexity and abstractness (Anderson 1998), and narratives need to be taken into account, as national considerations cannot be underestimated and can guide citizens' orientation towards the EU (see also Kritzinger 2003; Guerra 2013).

As Liesbeth Hooghe argued, in the introduction to a special issue on drivers of EU integration, EU politics and integration have increasingly become more controversial and explanations found empirical evidence based on different frameworks and dynamics (2007; see also Börzel 2005; Risse 2005). Nonetheless, none of these studies attempted to define public attitudes to understand and define the different degrees and characteristics of citizens' view about the EU, beyond perceived subjective domestic costs and benefits ratio (Guerra 2013) and domestic benchmarks (De Vries 2018).

As stressed by Daddow in the case of the New Labour government, 'positive European values would have meant currently apathetic or sceptical members of the public becoming comfortable with the idea of multilevel identities as British and European, and beginning to think 'European' (2011: 34). This analysis takes into account the characteristics of the current phenomenon of Euroscepticism and its different connotations, where both negative and neutral views can be traced. It is further critical to note the role of the media, as the UK case study shows (Daddow 2012), that can channel and perpetuate the image of the EU, as framed in the news, in the public debate. Yet, Patrick Bijsmans (2017) stresses there is likely a critical positive attitude, supporting the polity, but opposing policies and debates (ie: Euroalternativism), with further differences across national media debates (Bijsmans et al. 2018).

This analysis suggests that contemporary forms of public Euroscepticism would require a more detailed in-depth study at the mass level, reconciling both case studies and comparative research designs, and political science and European Studies traditions. Due to the changing nature of public Euroscepticism and its persistence, this study contends that research contributions could reflect on contemporary developments. Euroscepticism and contestation towards the EU ring a bell, and it is more important to understand what Euroscepticism signals in order to understand it, now that contestation does not necessarily translate into Euroscepticism.

Euroscepticism may not have an impact of the policymaking process at the EP level, because Eurosceptic MEPs may be split among different political groups (McDonnell and Werner 2019), but the EU is definitely more contested (Hutter et al. 2016).Their presence at the heart of the EU is an asset for its legitimation, MEPs represent EU citizens and opposition and resistance to the 
EU should not be routinely viewed as an obstacle to EU integration, but also as a resource for the affirmation of the EU as democratic political system (Brack 2015), with Euroscepticism (Stier et al. 2020). The study of Euroscepticism can further develop, not just moving, as it has been done, from dependent variable to independent variable and its influence and impact, but also examining its different manifestations at the public level, understanding its narratives, listening to people's voices. The British referendum is here examined by exploring the relationship between citizens and the $\mathrm{EU}$, and addressing what we can learn from after the British referendum.

\section{LISTENING TO PEOPLE'S VOICES}

In April 2019, the research project, 'Euroscepticism, Emotions and the Everyday', commissioned 11 questions for a new YouGov survey, with a representative sample of 1813 British citizens. If good news seems to be fleeting, messages and narratives could be structured through 'hot points' (Interview 2018), events that have characterized moments between the EU and each member state, and can transform the national narrative beyond temporary debates. The main focus of the study here examines the national narratives on the EU, after the extended departure from the EU. These 'hot points' in the national narratives, influenced by the domestic context, can more easily be mobilized and affect citizens' emotions and their experience. This is the main research interest here: What are the national narratives on the EU, when you directly ask citizens?

The question asked reads as follows, 'Thinking about the history of Britain's membership of the EU... What 4 events would you say are the most notable in Britain's membership of the EU?'

More than half of the respondents could not cite any event and answered 'I don't know' (54.8 per cent), and

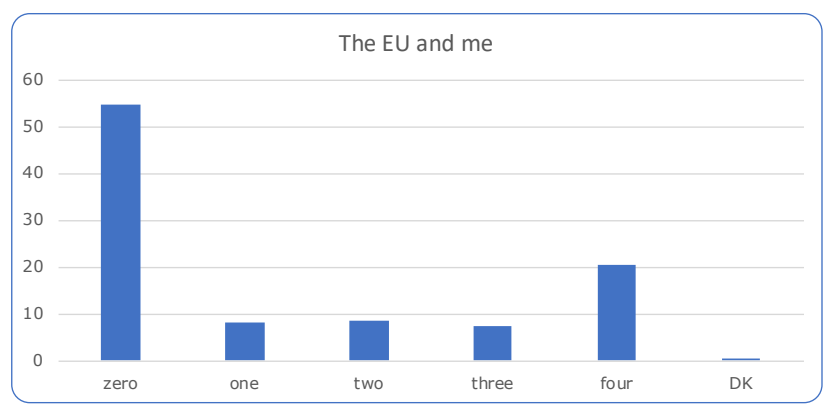

Figure 1. Britain and the EU: 'Thinking about the history of Britain's membership of the EU... What 4 events would you say are the most notable in Britain's membership of the EU?' less than a fourth (20.7 per cent) could cite four events or four dimensions.

Among the answers, nine respondents cite 'bananas', 'Banana making sure they are not straight', while the Common Agricultural Policy emerged also in terms of 'Butter mountains'. Just one person cites 'solidarity', 'solidarity following attacks', with reference to the 2017 London Bridge terrorist attack or the 2005 one. Four cite 'cooperation', and a majority, among the list of events/ hot points, (52) cite 'human rights', 'Agreeing and abiding by common values for human rights'. 14 cite immigration, quite often in negative terms and with reference to the Labour government, 'Labour opening the floodgates to mass immigration'.

\section{Deconstructing people's voices}

After examining the answers provided, it was clear that those who could articulate better the EU, also added some significant hot points, and most of the four hot points. Britain and the EU could thus represent,

N164: (i) Peace and good relationships with European neighbours; (ii) Trade with EU; (iii) Free movement of people across Europe, including to UK; (iv) No issues with NI/Republic border

N338: (i) Better workers rights and conditions [sic.]; (ii) Better conservation (natural environment) measures; (iii) Better bathing water quality; (iv) Freedom of movement, easier to learn from other cultures

N520: (i) Joining in 1973 on the third attempt.; (ii) The Thatcher rebate on Britains [sic.] membership (1980s?).; Britain is able to opt out of adopting the Euro.; (iv) Harmonisation of security policies.

N719: (i) The Schengin [sic.] Agreement which we foolishly opted out of which would have given us totally free movement with no need of passports.; (ii) The Maastricht Treaty which gave us commonality on security. Now superceded [sic.] by the Lisbon Treaty.; (iii) Europol which was formed to combat serious international crime and terrorism.; (iv) European Time Directive which gave us a maximum 48 hour week.

N1114: (i) Clean beaches; (ii) Financial growth; (iii) Status within the world; (iv) Improved labour rights.

N1130: (i) Free trade with Europe; (ii) easy travel/ movement in the EU; (iii) A united voice against world problems; (iv) Greater protection of rights for individuals. 
N1762: (i) Workers rights directive; (ii) Policy on environment (Paris accord); (iii) Policy on corporate tax evasion; (iv) Sending the idiot/Racist Nigel Farage to be our representative in the EU!

In some cases, it also provided the flow of opposing views to the EU,

N44: Germany opening the borders to all comers be they terrorists or not; (ii) Germany insisting on uncontrollable immigration; (iii) The cost of membership; (iv) The tariffs \& the French dominated CAP.

N104: (i) Joining under false pretences-Common Market-not!; Not joining the Euro-thank god !; (iii) Masstricht treaty; (iv) Voting to Leave [sic.]

N112: (i) immigrants; (ii) immigrants; (iii) lost power of laws; (iv) crap

N143: (i) Governed by unelected European beaurocrats [sic].; (ii) Pay through the nose to the EU and create ridiculous EU laws that we are obliged to comply with.; (iii) Create food mountains and pay producers even though there is a glut.; (iv) EU Crippled the British fishing industry.

N159: (i) paying millions over the years to subsidise 20 odd other poorer countries; (ii) Labour opening the floodgates to mass immigration; (iii) David Cameron coming back with his tail between ihis legs; (iv) giving away our fishing industry and selling off the utilities to foreign countries [sic.]

N261: (i) The Common Market becoming part of the EU in 1973, mainly for trade.; (ii) The idiots, and crooks who are part of the EU, headed by Junker; (iii) David Cameron walking away without a Plan B after the Referendum in 2016; (iv) The absolute farce of what has happened about us leaving the $\mathrm{EU}$ and the delays and indecisions.

N398: (i) immigration; (ii) control of us; (iii) large contribution byUK [sic.]; (iv) dictatorship

N456: (i) paying to opt out of the euro.; (ii) paying large budgets to an organisation that is not audited and refuses to be audited.; (iii) financially supporting an organisation that was responsible to the wine lake and butter mountain; (iv) financially supporting an organisation that allows migration of too many foreign nationals - too many to be integrated into the local ways of life without strife e.g. German problems at New Year.
N519: (i) us paying vast AMOUNTS OF MONEY TO THE EU; (ii) EU DEMANDING MORE MONEY BECAUSE OF THE BLACKMARKET ECONOMY; (iii) FRANCE WANTING MORE FISHING RIGHTS; (iv) BLAIR GIVING BACK THE CONCESSIONS tHATCHER WON [sic.]

In general, the negative ones show the main tropes and logics already seen in previous research (Daddow 2006, 2011; Fanoulis and Guerra 2017). While analysis on attitudes tend to focus on generalizable explanations, listening to people's voices enables us to understand how a few logics are embedded in their perception of the EU. In opposition, the EU is mainly seen as a cost, an open door for uncontrolled immigration, and limiting the scope to govern for Britain, losing out due to EU membership. The EU is perceived through the main debates filtered by the press and political debates. More objective views generally show a more sophisticated understanding or a rather inclusive view of the other, as cooperation, and the advantages of membership. In a case, a rather Eurosceptic respondent cited as one of the two 'hot points', the pet passport, adding, with surprise, that 'it works!'.

Definitely, EU membership seems to require the experience of citizenship (see Guerra and Serricchio 2014; Kuhn 2015) or a sophisticated understand of what membership means, in a country, Britain, where levels of knowledge about the EU are abysmal (Manners, 2018), and the older, 'the least knowledgeable, most incorrect, and most unable to answer simple questions on the EU' (in Manners, 2018: 1215). As Taggart and Szczerbiak (2014) pointed out, there exists research on public opinion on EU integration, but less on the drivers of the opposition and how this opposition emerged across public opinion. This analysis seeks to examine the issues and moves beyond the study of attitudes to understand the national narratives that mobilize citizens.

By narratives, this project addresses those written accounts and events that are shared across the national context. The relevant characteristics of the history of EU integration at the domestic level and the debates originated within that context (as hot points) emerges while listening to citizens' voices. 'Hot points' traced through the history of EU integration at the national level could help communicate the EU itself, 'the Irish case could be described through a non-confrontational forum towards the peace process, the economic boom, structural funds (roads) and best chance' (Interview 2018), by listening to British citizens, while the main narratives could also be framed through different logics. If the EU seems still to be slightly trapped into a national politicization, 
the recent 2019 EP elections show that it is possible to involve part of the citizens into a more transnational European debate.

Yet, during the British EU referendum campaign, when the European issue raised its salience, the former Mayor of London, currently Prime Minister, Boris Johnson, supporting Vote Leave, returned on the theme of common Euromyth among the British press. One of the most famous Eurosceptic journalists in Brussels between 1989 and 1994 for the Daily Telegraph, Johnson was probably quite acquainted with the banana stories, more recently compared to their first debut in the UK. (Earle 2018)

The first piece of news around the EU banning round bananas was published in 1994 (European Parliament 2019a), and published by four newspapers, The Sun, Daily Express, Daily Mail, and Daily Mirror. The headline, "Curved bananas have been banned by Brussels bureaucrats, with shops ordered not to sell fruit which is too small or abnormally bent" (21 September 1994) can be dissected to bring together different British Eurosceptic logics (see also Fanoulis and Guerra 2017), that have remain embedded in the narratives we have seen in the 2016 referendum campaign. These logics are strengthened by the often cited use of words as 'Brussels' and 'bureaucrats', but also 'Eurocrats', dictating to Britain. This node underlines 'British difference' from the continent (Daddow 2006: 315). On the contrary, Brussels triggers suspicion, and distrust towards European leaders, it becomes the cradle of corruption and mishaps. Whatever related to the EU enters the British debates as an 'illegitimate intrusion ... which has become part of the political culture of British EU membership and its reporting in the tabloid press' (Daddow 2006: 315). In addition, the reference to 'shops' (ie: British shops), in the headline, represents the threat of EU membership against working class people who struggle in their everyday life (Fanoulis and Guerra 2017). Defending Britain against the $\mathrm{EU}$ is also defending the interests of the common British citizens.

A similar logic resurfaced during the referendum campaign and just after. The idea is that 'EU policy regulations harm British producers and the British market', 'let the farmers sell what they produce and compete with the supermarkets! The supermarkets have had a hold of the farmers and the public for far too long!! [sic] (13 July 2016)' (Fanoulis and Guerra 2017: 319). The perceived 'abuse' of the EU on local and national British interests is linked to the same logic when applied at a higher level. Daddow notes the same in The Sun, where also simple comments on Britain's European policy could be reported using the same narrative,
The continent acts out its role of the threatening Other across the Channel with those 'lesser breeds', the French and the Germans, playing the roles of untrustworthy Machiavellian villains leading its machinations against Britain. Compared to the trustworthy Americans, Anderson finds the Sun depicting the EU as 'a corrupt and untrustworthy interventionist predator, driven by a Franco-German plot to damage British economic interests, British security and British sovereignty...' (2006: 317)

The EU cannot be trusted, and Britain, geographically distant from the continent, has been perceiving the Franco-German alliance as a threat to British economic interests, security and sovereignty. These themes resurface, around a new article still published in The Sun (4 March 1998). The headlines point to the trivial dimension of $\mathrm{EU}$ politics and decision-making. Brussels is not just responsible of negatively affecting the economy of British farmers and the economy, but its institutions are not effective and do not have any positive influence on Britain. On the contrary, member states plot against Britain, and the EU cannot work on serious policy regulations. Yet, in both cases, the European Commission had recommended to draft legislation after receiving the request by individual governments and national agriculture ministers in order to harmonize standards across the EU. 'Following extensive consultation with the industry, the proposed quality standards were adopted by national ministers in Council in 1994.' (European Parliament 2019b), without receiving any reply from the British press.

Yet, new headlines, as still in The Sun, on Monday 18 February 2013, addressing another important narrative in the British press, the unsustainable cost of

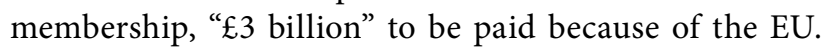
The article was presented as an EXCLUSIVE [sic.], and the headline in bold. The news was referring to a share of POSEI (EU Fund for Remote countries or Islands, 'Programme d'Options Spécifiques à l'Éloignement et l'Insularité'), defined as 'colonies' in the original article. The news was framed as if the EU would hand out 'BILLIONS [sic.] ... on paradise isles'. This is a narrative that has been continuously repeated, during the referendum campaign, the Leave.EU blog reported the post of a British citizens complaining about the waste of money and the 'giver' role of Britain,

Every week an enormous sum is paid to the EU ... Most EU countries are takers, it is spent anywhere other than in Britain. $£ 100 \mathrm{M}, £ 150 \mathrm{M}, £ 200 \mathrm{M}, £ 250 \mathrm{M}, £ 300 \mathrm{M}$... it's a truly colossal, massive, enormous amount-Every week. (Fanoulis and Guerra 2017: 317)

The money spent for the EU has been the most successful for the Leave.EU campaign. Narratives, through 
psychological realism, as the red bus and the $£ 350$ million that can be saved to be spent on the NHS (National Health Service) instead, brought together different connotations that could positively affect support for Leave among British citizens. Since 1948, the NHS in the UK is one of the biggest employer in the world, and one of the most efficient and inclusive. The comparisons in the newspapers (see for example, Moran 2018) are generally done with the USA, or New Zealand, in this case, or other Commonwealth countries, as the efficiency and the quality of the service is done within the Commonwealth Fund report too, the reference to the NHS shows to what extent embedded national discourses can be strengthened and diffused.

On a similar theme dimension, the reference is to 'wasting money', generally for poorer countries or supporting a corrupt bureaucracy. Here The Sun story underlines that 'Brussels is handing out BILLIONS to banana, tobacco and rum industries on paradise isles [it was revealed yesterday]' [sic.], showing a few inconsistencies. As reported by the European Parliament, POSEI funding data are available since 2006 , and the data in the British article just provided a comparison of national income, not of the unemployment rate, and reference was done to remote 'small' islands, but not to their national governments, ie.: Spain and France, EU member states. The idea of the 'abuse' of British money is further linked to the reference to 'paradise isles' 'and to the reproduction of lines fed to it by a single anti-EU lobby group, with no balancing opinion.' (European Parliament 2019c). This type of messages returns and is often reproduced, as for the referendum campaign in 2016,

Every week an enormous sum is paid to the EU ... Sums are then sent back to be spent in Britain, the EU dictates what to be spent on. An eye watering remaining sum does not come back to Britain, it is spent in Poland, Greece, Romania, Slovakia-Most EU countries are takers, it is spent anywhere other than in Britain. $£ 100 \mathrm{M}, £ 150 \mathrm{M}$, $£ 200 \mathrm{M}, £ 250 \mathrm{M}, £ 300 \mathrm{M} \ldots$ it’s a truly colossal, massive, enormous amount-Every week (Fanoulis and Guerra 2017: 317)

The strength of these narratives that regularly return in the news, or we have seen in the referendum campaign, gains salience by being continuously repeated. (Krzyżanowski 2020) Studies show that Euroscepticism has generally low salience in the public debate (Szczerbiak and Taggart 2008), but it rises when the EU discourse becomes controversial at the domestic level. The European integration project has developed as an incremental, gradual and unspectacular process, and the EU is debated when there are more opportunities. Between
November 1987 and December 1995, the Eurobarometer surveys asked citizens whether they had recently seen or heard, in the papers, on the radio, or on television, anything about the European Commission in Brussels. Those replying they did represent a very low percentage, with the majority answering "No" or "Don't know". In 2008 only 44 per cent of citizens replied they were interested in EU affairs, with 58 per cent preferring reading about their country's politics (Special EB, 35 years of Eurobarometer, 2008). 'Between 1982 and 1992, a relative majority of people interviewed (44 per cent on average) had a positive view of the European Parliament. Nevertheless, on average, one in five (21 per cent) indicated that their perception of this institution was negative and for more than one in four (27 per cent) its image was neutral. (Daddow and Guerra 2019)

Similarly, according to a Centre of European Reform study in London, one of the most repeated arguments was that the Commission in Brussels 'dictated' 75 per cent of British laws, while a study of the House of Commons Library, showed that the percentage of secondary legislation resulting from EU requirements was about 8-10 per cent, mainly with regard to business regulation, VAT and excise duties. Also, it was reported that Britain daily contribution to the EU budget was $£ 50$ million - while the net contribution was 1 per cent of the total spending. Finally, when talking about the EU as the bureaucratic heart of Europe and the number of people employed, it is worth to be noted that the European Commission employs about 23,000 employees, and the European Parliament less employees compared to the Birmingham City Council (Daddow and Guerra 2019).

'Bananas', 'Brussels', 'dictating', and 'costs' returned in Boris Johnson's referendum campaign, in a speech in Cornwall in May 2016 (Henley 2016), and could succeed by linking the theme to traditional embedded narratives. According to Johnson, it was 'absolutely crazy that the EU [was] telling us how powerful our vacuum cleaners have got to be, what shape our bananas [had] got to be, and all that kind of thing', it was 'costing UK business-

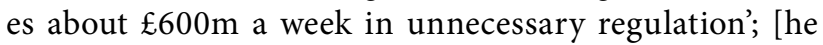
was] 'delirious' with Vote Leave's claim, repeated on the side of the battlebus, that Britain 'sends the EU $£ 350 \mathrm{~m}$ a week' (Henley 2016).

This British Euroscepticism that resurfaced and took strength with the EU referendum in 2016 is nothing new. As noted by Daddow:

Euroscepticism is more than myopic nationalism or the 'wrong' historical stories being told. It is both deeper than that. It is wider because Euroscepticism makes commercial intellectual sense (2006: 328). 
In a previous analysis, four logics (ie: narratives) clearly emerged from the analysis of the Leave-EU blog posts in the week before the referendum (Fanoulis and Guerra 2017), (i) a focus on sovereignty and the Leave vote to "get rid of" EU "dictatorship", as its policies harm "British producers and the British market" (13 July 2016), and voting Leave as patriotic duty; (ii) a dichotomous antagonistic relationship, and the idea that Britain can 'do better' outside the EU emerges, using a "us vs. them" dialectic, reversing history down, where voting "No" protects future generations; (iii) the moment to take history back, and EU membership as a mistake, a bad decision taken in the 1970s; (iv) increasing disillusionment with domestic political elites, sometimes defined as the 'the cronies', reinforced by the uncertain pace of the path towards Leave and the triggering of Article 50, with an embedded fear of immigration and the urgency of defending democracy as a priority in taking a final decision (Fanoulis and Guerra 2017).

Euroscepticism and opposition towards the EU cannot be understood far from its context. The time of its emergence also signal its possible success, and the use of colours (red, ie.: bus), and narratives ('Governed by unelected European beaurocrats' [sic.]', and tropes bring back the British Eurosceptic toolbox together: it is about British democracy, sovereignty, the high costs that impoverish our farmers and fisheries, the trivial work of unelected corrupt bureaucrats, the uncontrolled flow of immigration, and the political elites (Blair, Gordon Brown, Merkel, Juncker among the ones cited both in blogs and in the survey here used) and institutions (generally the European Commission) that opened their doors to this chain of events. Although only 20 per cent could provide four hot points in the history of Britain's relationship with the EU, citizens' voices show how fundamental they are in order to understand public Euroscepticism.

\section{CONCLUSION}

The analysis sought to provide a new approach to investigate and understand public Euroscepticism. Opposition towards EU integration emerges from its domestic context, from a national toolbox that is easy to deconstruct when we understand its traditions and narratives. For researchers examining public opinion and EU integration the 2016 British EU referendum provides the opportunity to explore Euroscepticism in-depth and examine how it changes across time, within and outside Britain.

It is critical to examine and discuss the current challenges of the EU, and explore how the EU is debated and contested at the domestic level. This becomes more urgent now, and studies are emerging on what to do and how in terms of governability (see Fabbrini 2019), while Donald Tusk, President of the European Council (20142019) comments on Brexit as the vaccine against Euroscepticism. Since Spring 2018, results from the Eurobarometer surveys have not changed, and the majority of European citizens have indeed a positive image of the EU (40 per cent), higher that those replying they have a negative image of the EU (21 per cent) or neutral (37 per cent) (EB89 2018: 15), but domestic context deeply varies. Euroscepticism is likely to be here to stay, and this analysis seeks to offer a contribution on its manifestations and tools at the domestic level, and how narratives can accompany the idea of the EU across member states.

The case of the UK is paradigmatic and it magnifies how public Euroscepticism can highjack the public debates, and if it is reasonable and desirable to expect that the EU respond to the distance between the institutions and citizens. Remote governance is difficult to be communicated. If more and more mobile citizens can benefit from experiencing the EU, the vast majority of EU citizens still lack basic knowledge. If simple messages work in a Eurosceptic environment, can safety in quality food and drink products that are protected from imitations, on the basis of their origin and geographical status under EU law, make a difference? By presenting this basic information, in very simple terms, as for example, informing that 'Cornish pasty' is protected under EU law (Henley 2016), messages reveal the impact of EU membership on countries.

Starting from the initial questions, addressing the understanding Euroscepticism, and its emotions and narratives, it is clear that the national narratives are significant. As noted already by Daddow (2006, 2011), Euroscepticism is very much identifiable in the traditional narratives of Europe as the Other. It enters the British governability by 'dictating' and not offering a choice. It emerges through domestic political actors and news, where the narratives and logics that can more easily reach the public are introduced, and the actors and ideas are contained in a sort of national [in this case, British] toolbox. In Britain, as aforementioned, it contains, 'Brussels', 'bureaucrats' or 'Eurocrats', the verb to 'dictate', and [the enormous] 'costs' that could be used for the NHS or British farmers and fisheries. It is about democracy and sovereignty, supporting Leave during the referendum campaign was also to protect Britain. At a very colloquial level, staying in the $\mathrm{EU}$, as one of the respondent said, represents the '[A]mount of money we give them.' (N546); 'The waste of money has been incredible. e.g. MEP's expenses, and the monthly move to 
Strasbourg.' (N847); 'Have to have their rules that don't apply to us' (N882); 'Having to abide by laws about this country made by other countries', 'Right size and shape of fruit and veg!' (N1003). The EU is perceived through very simple messages, often reconstructed by the national narrative that is often not accurate - further ignoring also the information provided by the European Commission Office in London (European Parliament 2019c).

Galpin and Trenz (2019) already pointed to the diffuse negativity in the UK media. The comparative analysis of their study on the 2014 European Parliament elections shows that by addressing a distinction between the polity, policy and political debates as diffuse, and specific issues, both UK actors and news tend to speak negatively about the EU. Context accountability (Daddow 2006) is still cause for concern in Britain and by assuming a more positive view of European Britain, as pitched well by Daddow (2006) does not make the debate more informed. Images, narratives and specific issues can become very simple images and narratives and reform the Eurosceptic toolbox into a more neutral, but informative instrument. This should be done at the grassroots level, as the recent demos and manifestations have shown. British citizens are reclaiming their own European citizenship, and losing the free movements is not worth to pay for most of those who voted Remain, but also some Leavers. Deconstructing Euromyths could be a first small step forward.

\section{REFERENCES}

Anderson, C.J. (1998) 'When in Doubt, Use Proxies. Attitudes Toward Domestic Politics and Support for European Integration', Comparative Political Studies, Vol. 31, No. 5, pp. 569-601.

BBC (2017) 'Britons should keep EU rights post Brexit Guy Verhofstadt', 10 March, available at: https://www. bbc.com/news/uk-politics-39228245

BBC (2016) 'Thousands at "March for Europe" Brexit protest', 2 July, available at: https://www.bbc.com/ news/uk-36692990

Bijsmans, P. (2017) 'EU Media Coverage in Times of Crisis: Euroscepticism Becoming Mainstream?' in M. Caiani and S. Guerra (eds) Euroscepticism, Democracy and the Media: Communicating Europe, Contesting Europe, Palgrave Studies in European Political Sociology, pp. 73-94.

Bijsmans, P., Galpin, C. and Leruth, B. (2018) '"Brexit" in transnational Perspective: an analysis of newspapers in France, Germany and the Netherlands', Comparative European Politics, Vol. 16, No. 5, pp. 825-842. de Bois, S. and Hearn, J. (2017) Are men getting more emotional? Critical sociological perspectives on men, masculinities and emotions, The Sociological Review, Vol. 65, No. 4, pp. 779-796.

Börzel, T.A. (2005) 'Mind the Gap! European integration between level and scope', Journal of European Public Policy, Vol.12, No. 2, pp. 217-236.

Brack, N. (2015) 'The roles of Eurosceptic Members of the European Parliament and their implications for the EU, International Political Science Review, Vol. 36, No. 3, pp. 337-350.

Caiani, M. and Guerra, S. (eds.) (2017) Euroscepticism, Democracy and the Media: Communicating Europe, Contesting Europe, Palgrave Studies in European Political Sociology.

Daddow, O. (2013) 'Margaret Thatcher, Tony Blair and the Eurosceptic Tradition in Britain', British Journal of Politics and International Relations, Vol. 15, No. 2, pp. 210-222.

Daddow, O. (2012) 'The UK Media and "Europe": From Permissive Consensus to Destructive Dissent', International Affairs, Vol. 88, No. 6, pp. 1219-1236.

Daddow, O. (2011) New Labour and the European Union: Blair and Brown's Logic of History, Manchester: Manchester University Press.

Daddow, O. (2006) 'Euroscepticism and the Culture of Discipline of History', Review of International Studies, Vol. 32, No. 2, pp. 309-328.

Daddow, O. and Guerra, S. (2019) 'Scholars and the British Referendum', paper presented for the COST PRoSEPS project workshop, The Hague, 19-20 September.

De Vries, C.E. (2018) Euroscepticism and the Future of European Integration, Oxford: Oxford University Press.

Dutceac Segesten, A. and Bossetta, M. (2019) 'Can Euroscepticism Contribute to a European Public Sphere? The Europeanization of Public Discourses on Euroscepticism across Six Countries', Journal of Common Market Studies, Vol. 57, No. 5, pp. 1051-1070.

Earle, R. (2018) 'The day bananas made their British debut', The Conversation, 10 April, available at: https://theconversation.com/the-day-bananas-madetheir-british-debut-94742

Eurobarometer 89 (2018) 'Public opinion in the European Union', Standard Eurobarometer, Spring, Brussels: European Commission, available at: http://ec.europa. $\mathrm{eu} / \mathrm{comm}$ frontoffice/publicopinion/index.cfm/Survey/getSurveyDetail/instruments/STANDARD/surveyKy/2180

European Parliament (2019a) 'Bananas and Brussels', Euromyths, Brussels: European Parliament, last 
update (4 June 2019) available at: http://www.europarl.europa.eu/unitedkingdom/en/media/euromyths/ bendybananas.html

European Parliament (2019b) 'Curved bananas', Euromyths, Brussels: European Parliament, last update (4 June 2019) available at: https://blogs.ec.europa.eu/ ECintheUK/curved-bananas/

European Parliament (2019c) 'The Sun goes bananas for an anti - EU story', Euromyths, Brussels: European Parliament, last update (4 June 2019) available at: https://blogs.ec.europa.eu/ECintheUK/the-sun-goesbananas-for-an-anti-eu-story/

Eurosphere. 2013. "Diversity and the European Public Sphere. Towards a Citizens' Europe." Accessed at: http://eurosphere.uib.no/

Fabbrini, S. (2019) Europe's Future: Decoupling and Reforming, Cambridge: Cambridge University Press.

Fanoulis, E. and Guerra, S. (2017) 'Anger and protest: referenda and opposition to the EU in Greece and the UK', Cambridge Review of International Affairs, Vol. 30, No. 4: pp. 305-324.

FitzGibbon, J. (2013) 'Another Europe is possible' and the end of Euroscepticism? Addressing the fine-line between opposing Europe and offering a Euro-alternative', Paper presented at the UACES Annual Conference 2013, 5th September, University of Leeds.

Flood, C. (2002) 'Euroscepticism: A Problematic Concept', Paper presented to the UACES 32nd Annual Conference and 7th Research Conference, Queen's University Belfast, 2-4 September.

Gabel, M. J. (1998) Interests and Integration. Market Liberalization, Public Opinion and European Union, Ann Arbor: The University of Michigan Press.

Galpin, C. and Trenz, H.J. (2019) 'Converging towards Euroscepticism? Negativity in news coverage during the 2014 European Parliament elections in Germany and the UK', European Politics and Society, Vol. 20, No. 3, pp. 260-276.

Guerra, S. (2019) “Immigration, that's what everyone's thinking about ...” The 2016 British EU referendum seen in the eyes of the beholder, Journal of Language and Politics, Vol. 18, No. 5, pp. 651-670.

Guerra, S. (2013) Central and Eastern European Attitudes in the Face of Union, Basingstoke: Palgrave Macmillan.

Guerra, S. and Serricchio, F. (2014) 'Identity and Economic Rationality: Explaining Attitudes towards the EU in a Time of Crisis' in B. Stefanova (ed.) The European Union beyond the Crisis: Evolving Governance, Contested Policies, Disenchanted Publics, Lanham, MD: Lexington Books, Rowman \& Littlefield, pp. 269-294.

Guerrina, R., Exadaktylos, T. and Guerra, S. (2016) 'Brexit or Bremain: Britain and the 2016 British Referen- dum, Research project, (University of Surrey and University of Leicester, June-July).

Henley, J. (2016) 'Is the EU really dictating the shape of your bananas?', The Guardian, 11 May, available at: https://www.theguardian.com/politics/2016/may/11/ boris-johnson-launches-the-vote-leave-battlebus-incornwall

Hooghe, L. (2007) 'What Drives Euroskepticism?', European Union Politics, Vol. 8, No. 1, pp. 5-12.

Hooghe, L. and Marks, G. (2009) 'A Postfunctionalist Theory of European Integration: From Permissive Consensus to Constraining Dissensus', British Journal of Political Science, Vol. 39, No. 1, pp. 1-23.

Hutter, S., Grande, E. and Kriesi, H. (eds) (2016) Politicising Europe: Integration and Mass Politics, Cambridge: Cambridge University Press.

Kritzinger, S. (2003) 'The Influence of the Nation State on Individual Support for the European Union', European Union Politics, Vol. 4, No. 2, 219-241.

Krzyżanowski, M. (2020) 'Discursive Shift in/and the Normalisation of Racism: Imaginaries of Immigration and Moral Panics in the Discourse of Contemporary Right-Wing Populism, Social Semiotics, Vol. 20, No. 4, pp. 503-527.

Krzyżanowski, M. (2019) 'Brexit and the imaginary of 'crisis': a discourse-conceptual analysis of European news media', Critical Discourse Studies, Vol. 16, No. 4, pp. 465-490.

Kuhn, T. (2015) Experiencing European integration: Transnational Lives and European Identity, Oxford: Oxford University Press.

Manners, I. (2018) 'Political Psychology of European Integration: The (Re)production of

Identity and Difference in the Brexit Debate', Political Psychology, Vol. 39, No. 6, pp. 1213-1232.

Marcus, G. E. (2000) 'Emotions in Politics', Annual Review of Political Science, Vol. 3, pp. 221-250.

McDonnell D. and Werner A. (2019) 'The ENF Group in the European Parliament: A lasting transnational radical right populist group, Paper prepared for presentation to the 2019 EUSA International Biennial Conference, Denver, 9-11 May.

Moran, M. (2018) 'The NHS at 70: 5 reasons why Britain loves its National Health Service', The Mirror, 5 July, available at: https://www.mirror.co.uk/interactives/ nhs-70-5-reasons-britain-12854101

Risse, T. (2005) 'Neofunctionalism, European identity, and the puzzles of European integration', Journal of European Public Policy, Vol. 12, No. 2, pp. 291-309.

Risse, T. (2010) A Community of Europeans? Transnational Identities and Public Spheres, Ithaca: Cornell University Press. 
Stefanova, B. (ed.) (2014) The European Union beyond the Crisis: Evolving Governance, Contested Policies, Disenchanted Publics, Lanham, MD: Lexington Books, Rowman \& Littlefield.

Stier, S., Froio, C. and Schünemann, W.J. (2020) 'Going transnational? Candidates' transnational linkages on Twitter during the 2019 European Parliament elections', West European Politics, doi: 10.1080/01402382.2020.1812267.

Szczerbiak, A. and Taggart, P. (2008) Opposing Europe?: The Comparative Party Politics of Euroscepticism, Country Surveys and Theoretical Perspectives, Oxford: Oxford University Press, Vols. I \& II.

Taggart, P. (1998) 'A touchstone of dissent: Euroscepticism in contemporary Western European party systems', European Journal of Political Research, Vol. 33, No. 3, pp. 363-388.

Taggart, P. and Szczerbiak, A. (2014) 'Research on Euroscepticism', UK in a Changing Europe ESRC Initiative, available at: http://www.esrc.ac.uk/_images/executive-summary-taggart-szczerbiak_tcm8-33024.pdf.

Taggart, P. and Szczerbiak, A. (2002) 'The Party Politics of Euroscepticism in EU Member States and Candidate States', SEI Working Paper No. 51, Opposing Europe Research Network Working Paper No. 6, Falmer, Brighton: Sussex European Institute, University of Sussex.

Tsebelis, G. (2018) 'How Can We Keep Direct Democracy and Avoid "Kolotoumba" - Comment on "Proposals for a Democracy of the Future" by Bruno Frey', Homo Oeconomicus, Vol. 35, No. 1-2, pp. 81-90.

Tusk, D. (2017) 'Remarks by President Donald Tusk following the UK notification', 29 March, available at: https://www.consilium.europa.eu/en/press/pressreleases/2017/03/29/tusk-remarks-uk-notification/

Usherwood, S. and Startin, N. (2013) 'Euroscepticism as a Persistent Phenomenon', Journal of Common Market Studies, Vol. 51, No. 1, pp. 1-16.

Usherwood S., Startin N. and Guerra S. (eds.) (2013) 'Confronting Euroscepticism', Journal of Common Market Studies, Vol. 51, No. 1, January.

Wodak, R. and Angouri, J. (2014) 'From Grexit to Grecovery: Euro/crisis discourses', Discourse \& Society, Vol. 25, No. 4, pp. 417-423.

\section{INTERVIEWS}

Interview (2018) European Commission, Brussels, 28 June. 